\title{
PENYELESAIAN SENGKETA EKONOMI SYARIAH MELALUI BASYARNAS DITINJAU DARI ASAS KEPASTIAN HUKUM, KEADILAN DAN KEMANFAATAN
}

\author{
Syams Eliaz Bahri \\ Mahasiswa Pascasarjana ,Program Studi Hukum Ekonomi Syariah \\ Institut Agama Islam Negeri Batusangkar \\ syams.eliaz@gmail.com
}

\begin{abstract}
Abstrak: This research was aimed at analyzing the resolution dispute of sharia economic through BASYARNAS in terms of legal certainly, justice, and benefits. BASYARNAS was born as a response to the development of sharia financial institutions. The verdict issued by the arbitration body (BASYARNAS) is final and binding. In this case whether the dispute settlement through BASYARNAS has reflected the value of legal certainty, justice and expediency. This research is qualitative with normative juridical approach, data obtained from literature study and analyzed qualitatively. The results of this research seen the overlapping law that resulted in confusion on the execution of the decision BASYARNAS. The overlapping law esulted in the non-creation of legal certainty and made it difficult for justice seekers.
\end{abstract}

Keywords: Execution Decision, Overlapping Law, BASYARNAS

\section{PENDAHULUAN}

Praktek ekonomi syariah pada masa sekarang semakin berkembang. Secara praktis, perkembangan tersebut dapat dilihat dengan munculnya lembaga keuangan yang berlabelkan "syariah" sebagai bentuk jati dirinya menerapkan produk dan transaksi sesuai syariat Islam.

Ide mendirikan bank syariah muncul sejak tahun 1970 an. Pendirian pertama kali bank syariah di Indonesia ditandai dengan ditandatanganinya akta pendirian Bank Muamalat pada tanggal 1 November 1991 yang kemudian resmi beroperasi pada tanggal 1 Mei 1992 (Dewi, 2006: 59). Seiring berjalan waktu, perkembangan lembaga keuangan syariah semakin pesat, dan transaksi-transaksi yang berkembangpun semakin banyak. Namun dalam transaksi yang dilakukan tidak jarang munculnya sengketa.

Kemungkinan-kemungkinan munculnya sengketa biasanya berupa pengaduan karena terjadi ketidaksesuaian 
antara realitas dan alur birokrasi yang tidak masuk dalam draf akad, serta komplain tentang hambatan proses kerja (Ansori, 2007: 182). Sengketa juga dapat terjadi disebabkan para pihak atau salah satu pihak melakukan wanprestasi atau ingkar janji. Wanprestasi dapat terjadi dalam bentuk:

1. Tidak melakukan apa yang disanggupi akan dilakukaknnya;

2. Melaksanakan apa yang dijanjikan, tapi tidak sebagaimana yang dijanjikan;

3. Melakukan apa yang dijjanjikan tapi terlambat;

4. Melakukan sesuatu yang menurut kontrak tidak boleh dilakukan. (Saliman, 2005: 41)

Dalam menyelesaikan sengketa yang timbul, langkah-langkah yang dapat ditempuh untuk menyelesaikan sebuah sengketa atau perselisihan tersebut terbagi kepada penyelesaian secara ligitasi dan secara non litigasi.

Pada jalur litigasi atau peradilan pasca diundangkannya Undang-Undang Nomor 3 Tahun 2006 Tentang Perubahan Atas Undang-Undang Nomor 7 Tahun 1989 Tentang Peradilan Agama (selanjutnya ditulis UU No. 3 Tahun 2006) badan peradilan yang berwenang menangani perkara ekonomi syariah adalah Peradilan
Agama. Hal ini merupakan hal yang wajar mengingat Peradilan Agama adalah pengadilan yang ditujukan untuk orangorang Islam sebagaimana dijelaskan dalam Pasal 1 ayat (1) Undang-Undang Nomor 7 Tahun 1989 Tentang Peradilan Agama (selanjutnya ditulis UU No. 7 Tahun 1989).

Dilain pihak, penyelesaian sengketa ekonomi syariah juga dapat melalui jalur non litigasi. Mengenai bentuk-bentuk penyelesaian sengketa secara non litigasi, Joni Emirzon menyatakan saat ini yang paling umum adalah negosiasi, mediasi, konsiliasi, arbitrase (Emrizon, 2008: 431).

Kekuatan hukum lembaga arbitrase dalam menyelesaikan sengketa ekonomi dapat dilihat dari Undang-Undang Nomor 30 Tahun 1999 Tentang Arbitrase Dan Alternatif Penyelesaian Sengketa (selanjutnya ditulis UU No. 30 Tahun 1999). Pada Undang-undang tersebut dijelaskan bahwa Arbitrase berwenang menyelesaikan sengketa perdata jika ada perjanjian tertulis yang dibuat antara para pihak. Sehingga berdasarkan hal ini, proses penyelesaian sengketa bidang perdagangan dan mengenai hak yang menurut hukum dapat diselesaikan melalui jalan arbitrase. Selain melalui jalur arbitrase, dalam UU No. 30 Tahun 1999 Pasal 1 ayat (10) menyatakan bahwa alternatif penyelesaian sengketa 
dapat melalui jalur konsultasi, negosiasi, mediasi, konsiliasi, atau penilaian ahli.

Pasca lahirnya Bank Muamalat muncul gagasan akan pentingnya lembaga arbitrase Islam di Indonesia. Gagasan ini diawali dengan bertemunya para pakar, cendekiawan muslim, praktisi hukum, para kyai dan ulama. Pertemuan ini dimotori Dewan Pimpinan Majelis Ulama Indonesia (selanjutnya ditulis MUI) pada tanggal 22 April 1992. Setelah pertemuan tersebut, pada tanggal 23 Oktober 1993 Badan Arbitrase Muamalat Indonesia (selanjutnya ditulis BAMUI) diresmikan, kemudian sejak tanggal 24 Desember 2003 organisasi ini berubah nama, dan hingga saat ini lebih dikenal dengan Badan Arbitrase Syariah Nasional (selanjutnya ditulis BASYARNAS) (Sumitro, 2004: 167).

Sebagai lembaga arbitrase, keberadaan BASYARNAS mengikuti aturan dalam UU No. 30 Tahun 1999. BASYARNAS yang didirikan sebagai lembaga arbitrase dengan prinsip syariat Islam diharapkan akan dapat menerima, memeriksa, dan mengadili perkara-perkara sengketa ekonomi syariah. Hal ini merupakan tantangan tersendiri untuk BASYARNAS dikarenakan pesatnya pertumbuhan Lembaga Keuangan berprinsip Syariah. Di sisi lain, meskipun putusan yang dikeluarkan BASYARNAS bersifat final and binding, namun BASYARNAS tidak dapat melakukan eksekusi sendiri ketika putusan tersebut tidak dijalankan. Berdasarkan hal di atas penulis ingin meneliti lebih jauh tentang Penyelesaian Sengketa Ekonomi Syariah Melalui BASYARNAS Ditinjau Dari Asas Kepastian Hukum, Keadilan Dan Kemanfaatan.

\section{KAJIAN TEORI}

\section{Kedudukan Basyarnas dalam Penyelesaian Sengketa Ekonomi Syariah}

Beberapa faktor yang melatarbelakangi berdirinya lembaga arbitrase berdasarkan syari'at Islam adalah semakin maraknya kesadaran dan keinginan umat terhadap pelaksanaan hukum Islam, disamping juga karena faktor pertumbuhan dan perkembangan lembaga-lembaga keuangan syari'ah yang semakin pesat di Indonesia, khususnya sejak berdirinya Bank Muamalat Indonesia tahun 1992. (Dimiyati, 1994: 191) Sebagai lembaga arbitrase, BAMUI bertugas sebagai lembaga:

1. Penyelesaian sengketa yang timbul dalam hubungan perdagangan, industri, keuangan, jasa, dll dimana para sepakat secara tertulis untuk menyerahkan penyelesaiannya kepada BAMUI sesuai peraturan prosedur BAMUI;

2. Memberikan suatu pendapat yang mengingat tanpa adanya suatu sengketa 
mengenai suatu persoalan berkenaan dengan perjanjian permintaan para pihak (Sumitro, 1997, 149).

Sebagai lembaga alternatif penyelesaian sengketa kewenangan BASYARNAS dalam menyelesaikan sengketa ekonomi syariah dapat terlihat dari beberapa faktor:

\section{Asas Kebebasan Berkontrak}

Dalam suatu perjanjian dikenal adanya asas kebebasan berkontrak. Asas ini menyatakan bahwa suatu perjanjian yang dibuat harus atas persetujuan kedua belah pihak. Dalam Pasal 1321 Kitab UndangUndang Hukum Perdata (selanjutnya ditulis KUHPer) dijelaskan bahwa tiada sepakat yang sah apabila sepakat itu diberikan karena kekhilafan atau diperoleh dengan paksaan atau penipuan.

Berdasarkan pasal ini terlihat bahwa suatu perjanjian yang dibuat harus terkandung kesepatan antara kedua belah pihak. Ketika salah satu pihak tidak ingin melakukan perjanjian, mereka tidak dapat dipaksa, dan mereka yang terpaksa dalam mengadakan perjanjian dapat melakukan pembatalan terhadap perjanjian tersebut.

Uraian yang senada juga dijelaskan dalam Kompilasi Hukum Ekonomi Syariah (selanjutnya disebut KHES) Pasal 21 huruf a yang menyatakan bahwa dalam suatu perjanjian harus terdapat Ikhtiyari/ sukarela. Setiap akad dilakukan atas kehendak para pihak, terhindar dari keterpaksaan karena tekanan salah satu pihak atau pihak lain. Adanya sukarela antara yang mengadakan perjanjian agar terhindarnya dari kezaliman sebagaimana dijelaskan dalam KHES Pasal 21 huruf $\mathrm{j}$ tentang Itikad baik. Maksudnya adalah akad dilakukan dalam rangka menegakan kemaslahatan, tidak mengandung unsur jebakan dan perbuatan buruk lainnya.

Dalam Pasal 1338 KUHPer dijelaskan bahwa ketika telah terjadi semua perjanjian yang disebabkan suka sama suka, maka semua persetujuan tersebut berlaku sebagai undang-undang bagi mereka yang membuatnya. Persetujuan itu tidak dapat ditarik kembali selain dengan kesepakatan kedua belah pihak, atau karena alasanalasan yang ditentukan oleh undangundang. Persetujuan harus dilaksanakan dengan itikad baik

Berdasarkan hal ini dapat terlihat bahwa semua perjanjian dinyatakan sah jika perjanjian tersebut diadakan atas dasar sukarela. Sukarela dalam perjanjian tersebut mencakup objek perjanjian, serta semua poin dalam perjanjian. Suatu perjanjian yang sah akan berlaku seperti undang-undang bagi mereka yang berjanji. 
Jika diperhatikan pada Pasal 1338 KUHPer terdapat 3 pokok yang terkandung di dalamnya:

1. Pada kalimat "semua perjanjian dinyatakan sah" menunjukan asas kebebesan berkontrak.

2. Pada kalimat "berlaku sebagai undangundang" menunjukkan asas kekuatan mengikat atau asas pacta sun servanda.

3. Pada kalimat "bagi mereka yang membuatnya" menunjukkan asas personalitas. (Miru dan Pati, 2008: 78)

\section{Undang-Undang Nomor 30 Tahun 1999 Tentang Arbitrase Dan Alternatif Penyelesaian Sengketa}

Kedudukan BASYARNAS dalam menyelesaikan sengketa ekonomi syariah juga dapat terlihat dari UU No. 30 Tahun 1999. Meskipun Undang-undang ini tidak khusus menjelaskan tentang Basyarnas, tapi dikarenakan BASYARNAS merupakan lembaga Arbitrase maka BASYARNASjuga termasuk dalam pemabahasan Undangundang ini.

Kedudukan lembaga Arbitrase dalam hal ini BASYARNAS sebagai lembaga penyelesaian sengketa dapat terlihat dalam Pasal 7, Pasal 1 ayat (3), Pasal 9, Pasal 5 ayat (1), Pasal 3 dan Pasal 11 UU No. 30 Tahun 1999.

Pada Pasal 7 UU No. 30 Tahun 1999 menyatakan bahwa "para pihak dapat menyetujui suatu sengketa yang terjadi atau yang akan terjadi antara mereka untuk diselesaikan melalui arbitrase". Berdasarkan hal ini terlihat bahwa selain melalui jalur litigasi, lembaga arbitrase (non litigasi) dapat menjadi pilihan untuk tempat penyelesaian sengketa. Pada Pasal 1 ayat (3) UU No. 30 Tahun 1999 dijelaskan perjanjian arbitrase adalah suatu kesepakatan berupa klausula arbitrase yang tercantum dalam suatu perjanjian tertulis yang dibuat para pihak sebelum timbul sengketa, atau suatu perjanjian arbitrase tersendiri yang dibuat para pihak setelah timbul sengketa.

Berdasarkan Pasal 1 ayat (3) UU No. 30 Tahun 1999 tersebut terlihat bahwa perjanjian penyelesaian sengketa melalui arbitrase bisa dilakukan sebelum adanya sengketa yang termuat dalam perjanjian tertulis, ataupun dapat dilakukan ketika terjadi sengketa dalam perjanjian tersendiri. Dalam Pasal 9 ayat(1) UU No. 30 Tahun 1999 dijelaskan bahwa persetujuan penyelesaian sengketa melalui arbitrase setelah sengketa terjadi harus dibuat dalam suatu perjanjian tertulis yang ditandatangani oleh para pihak. Namun, apabila para pihak tidak dapat menandatangani perjanjian tertulis tersebut, dalam Pasal 9 ayat (2) UU No. 30 Tahun 1999 dijelaskan perjanjian tertulis tersebut harus dibuat dalam bentuk akta notaris. 
Berdasarkan beberapa pasal di atas terlihat bahwa penyelesaian sengketa melalui arbitrase diperbolehkan, namun hanya terbatas pada sengketa di bidang perdagangan dan mengenai hak yang menurut hukum dan peraturan perundangundangan dikuasai sepenuhnya oleh pihak yang bersengketa sebagaimana dijelaskan dalam Pasal 5 ayat (1) UU No. 30 Tahun 1999.

Ketika perkara yang disengketakan memenuhi Pasal 5 ayat (1) UU No. 30 Tahun 1999 di atas dan para pihak telah bersepakat untuk menyelesaikan perkara mereka melalui lembaga arbitrase, maka lembaga lain termasuk lembaga peradilan (litigasi) tidak berwenang menangani perkara tersebut. Hal ini dijelaskan dalam Pasal 3 UU No. 30 Tahun 1999 "Pengadilan Negeri tidak berwenang untuk mengadili sengketa para pihak yang telah terikat dalam perjanjian arbitrase" dan juga terlihat pada Pasal 11 ayat (1) UU No 30 Tahun 1999 "Adanya suatu perjanjian arbitrase tertulis meniadakan hak para pihak untuk mengajukan penyelesaian sengketa atau beda pendapat yang termuat dalam perjanjiannya ke Pengadilan Negeri".

\section{Undang-Undang Nomor 21 Tahun 2008 Tentang Perbankan Syariah}

Kedudukan BASYARNAS sebagai salah satu lembaga yang berwenang menyelesaikan sengketa ekonomi syariah secara non litigasi juga terlihat dalam Undang-Undang Nomor 21 Tahun 2008 Tentang Perbankan Syariah (selanjutnya ditulis UU No. 21 Tahun 2008). Berdasarkan UU ini dijelaskan pada bagian penyelesaian sengketa Pasal 55 ayat (1) bahwa penyelesaian sengketa pada perbankan syariah diselesaiakan melalui Peradilan Agama.

Peradilan Agama sebagai lembaga peradilan bagi orang-orang Islam mempunyai kewenangan absolute baru sejak diundangkannya UU No. 3 Tahun 2006. Pada Pasal 49 undang-undang tersebut membahas tentang kewenangan peradilan agama, yang mana pada pasal tersebut menyatakan bahwa peradilan agama memiliki wewenang baru yaitu kewenangan menyelesaiakan sengketa ekonomi syariah.

Sehingga ketentuan dalam Pasal 55 ayat (1) UU No 21 Tahun 2008 yang menyatakan bahwa peradilan agama adalah lembaga yang berwenang dalam menyelesaikan sengketa ekonomi syariah menjadi wajar. Namun pada Pasal 55 ayat (2) UU No 21 Tahun 2008 menyatakan bahwa "Dalam hal para pihak telah memperjanjikan penyelesaian sengketa selain sebagaimana dimaksud pada ayat (1), penyelesaian sengketa dilakukan sesuai dengan isi Akad".

Berdasarkan Pasal 55 ayat (2) UU No 21 Tahun 2008 inilah BASYARNAS 
dapat menjadi pilihan penyelesaian sengketa ekonomi syariah khususnya perbankan syariah (dalam pasal ini). Pasal ini mengandung unsur asas kebebasan berkontrak, serta sesuai dengan Pasal 1338 KUHPer yang menyatakan bahwa kesepakatan yang dibuat bersama menjadi undang-undang bagi mereka. Ketika para pihak telah bersepakat dalam akad untuk menyelesaikan sengketa ke BASYRANAS, maka BASYARNAS yang berwenang menyelesaikan sengketa mereka.

\section{Undang-undang Kekuasaan Kehakiman}

Pada prinsipnya penyelesaian sengketa hanya dilakukan oleh kekuasaan kahakiman yang dilembagakan secara konstitusional nagara, yang dinamakan dengan lembaga yudikatif. Di Indonesia, sesuai dengan Pasal 24 Undang Undang Dasar 1945 (selanjutnya ditulis UUD 1945) yang berwenang memeriksa dan mengadili sengketa hanyalah badan peradilan yang bernaung di bawah kekuasaan kehakiman yang berpuncak pada Mahkamah Agung Republik Indonesia (selanjutnya ditulis MA) (Iska, 2012: 286).

Berdasarkan pasal 58-60 UndangUndang Nomor 48 Tahun 2009 Tentang Kekuasaan Kehakiman (selanjutnya ditulis UU No. 48 Tahun 2009) pada bagian penyelesaian sengketa di luar pengadilan dijelaskan bahwa upaya penyelesaian sengketa di luar pengadilan diperbolehkan.

\section{Kecenderungan dalam Penyelesaian Sengketa Ekonomi Syariah}

Sengketa dalam setiap transakasi tidak dapat dihindarkan, tidak hanya pada lembaga ekonomi konvensional, pada lembaga ekonomi syariah pun sengketa tersebut dapat terjadi. Dalam penyelesaian sengketa ekonomi syariah terdapat pilihan hukum yang dapat diambil. Pertama secara litigasi (badan peradilan). Kedua secara non litigasi. Menurut Suyud Margono Alternatif penyelesaian sengketa mempunyai daya tarik khusus karena keserasiannya dengan system social budaya tradisional yang berdasarkan musyawarah mufakat. Beberapa hal di bawah ini merupakan keuntungan yang sering muncul dalam Alternatif penyelesaian sengketa yaitu:

1. Sifat kesukarelaan dalam proses;

2. Prosedur yang cepat;

3. Keputusan nonyudisial;

4. Kontrol tentang kebutuhan organisasi;

5. Prosedur rahasia;

6. Fleksibilitas dalam merancang syaratsyarat penyelesaian masalah;

7. Hemat waktu;

8. Hemat biaya; 
9. Pemeliharaan hubungan;

10. Tingginya kemungkinan untuk melaksanakan kesepakatan;

11. Kontrol danlebihmudah memperkirakan hasil;

12. Keputusan bertahan sepanjang waktu. (Magono, 2000: 23)

Berdasarkan hasil penelitian Nurhasanah dan Hotnidah Nasution, faktor yang mempengaruhi lembaga keuangan syariah untuk memilih lembaga dan cara penyelesaian sengketa ekonomi syariah sangat beragam. Keberagaman pilihan tersebut yaitu: Pertama, faktor regulasi. Berdasarkan regulasi dan aturan yang ada, menjadikan lembaga keuangan dapat memilih lembaga penyelesaian sengketa mana yang akan digunakan.

Kedua, faktor asas kebebasan dalam berkontrak. Beragamnya klausul penyelesaian sengketa pada lembagalembaga keuangan syariah dimungkinkan karena adanya asas kebebasan berkontrak (party autonomy atau freedom of contract) sebagaimana diatur dalam Pasal 1338 ayat (1) KUH Perdata yang menyatakan bahwa semua perjanjian yang dibuat secara sah berlaku sebagai undang-undang bagi mereka yang membuatnya. Ketiga, faktor sumber daya manusia. Keempat, faktor kelembagaan. Kelembagaan yang dimaksud di sini adalah kompetensi lembaga yaitu pengadilan agama, pengadilan negeri dan BASYARNAS serta kompetensi para hakim dan para arbiter.

Kelima, faktor efisiensi waktu dan biaya. (Nurhasanah dan Nasution, Ahkam: Vol. XVI, No. 2, Juli 2016)

\section{METODE PENELITIAN}

Penelitian ini menggunakan metode penelitian kualitatif, dengan pendekatan yuridis normatif yang menekan kepada materi hukum. Penelitian yuridis normatif adalah penelitian yang mengacu pada norma hukum yang terdapat dalam peraturan perundang-undangan dan putusan/penetapan pengadilan (Ali, 2011: 105). Penelitian yang mengkaji ketentuanketentuan hukum positif maupun asasasas hukum. Dalam upaya memperoleh kebenaran ilmiah yang diharapkan, penelitian ini juga menggunakan beberapa pendekatan, yakni pendekatan UndangUndang (statute approach), pendekatan konseptual (consptual approach).

Dalam penelitian ini yang diteliti adalah kedudukan BASYARNAS dalam menyelesaikan sengketa ekonomi syariah. Hal ini akan dilihat dari peraturan perundang-undang yang menjadi landasan 
hukum BASYARNAS. Berdasarkan peraturan tersebut akan dilihat apakah peraturan tersebut sudah mengakomodir kewenangan BASYARNAS dalam menyelesaikan sengketa ekonomi syariah. Jadi objek penelitian ini adalah peraturanperaturan terkait dengan BASYARNAS.

Dalam melakukan penelitian ini, data yang digunakan berupa data sekunder yang sumber utamanya dari bahan hukum primer, yang terdiri atas: (Soejono dan Mamudji, 2007, 14)

a. Bahan hukum primer, yaitu bahanbahan hukum yang mengikat karena dikeluarkan oleh pemerintah dan berbentuk peraturan perundangundangan yang berhubungan dengan penelitian, seperti:

1) Undang-Undang Dasar Negara Republik Indonesia Tahun 1945;

2) Undang-Undang Nomor 30 Tahun 1999 Tentang Arbitrase dan Alternative Penyelesaian Sengketa;

3) Undang-Undang Nomor 21 Tahun 2008 Tentang Perbankan Syariah;

4) Kitab Undang-Undang Hukum Perdata;

b. Bahan hukum sekunder, yaitu bahanbahan yang memberikan penjelasan atau keterangan mengenai bahan hukum primer seperti, naskah akademik, rancangan Undang-Undang, risalah Undang-Undang, bukubuku yang ditulis oleh para sarjana hukum, laporan penelitian yang telah dipublikasikan, jurnal-jurnal hukum, artikel, makalah, situs internet dan lain sebagainya (Sumardjono, 2005: 14).

c. Bahan hukum tersier yaitu bahanbahan yang memberikan petunjuk maupun penjelasan terhadap bahan hukum primer maupun bahan hukum sekunder seperti kamus, ensiklopedia, dan sebagainya (Sumardjono, 2005: 14).

Dalam penelitian ini pengumpulan data dilakukan dengan cara studi kepustakaan, yaitu pengumpulan data dengan mencari konsepsi-konsepsi, teori-teori, pendapat, atau penemuan yang berhubungan erat dengan pokok permasalahan. Kepusatakaan berupa peraturan perundangan, karya ilmiah para sarjana, laporan lembaga, dan lain- lain sumber (Dimyati, 2004: 47).

Dalam melakukan Analisis Data, Data yang terkumpul dianalisis secara kualitatif. Data-data dari peraturan-peraturan tentang BASYARNAS serta contoh kasus tersebut dianalisis dan ditinjau melalui prespektif asas-asas peraturan perundang-undangan dan asas kepastian hukum. 


\section{HASIL PENELITIAN}

Dalam suatu perkara sengketa ekonomi syariah dimana para pihak dalam perkara ini adalah, PT ATRIUMASTA SAKTI sebagai Penggugat dan PT BANK SYARIAH MANDIRI sebagai Tergugat. Perkara ini telah bergulir hingga pada peninjauan kembali di MA.

Bahwa antara Penggugat dengan Tergugat telah terjalin suatu akad fasilitas pembiayaan murabahah dengan nominal 35 miliar rupiah. Dalam akad tersebut bentuk penyelesaian sengketa yang dipilih jika terdapat sengketa yang tidak dapat diselesiakan dengan musyawarah adalah melalui jalur non litigasi BASYARNAS.

Kemudian terjadi sengketa dan Penggugat mengajukan sengketa ini kepada BASYARNAS. Setelah melakukan pemerikasaan sengketa ini diputus Badan Arbitrase Syariah Nasional sebagaimana Putusan Nomor: 16/Tahun 2008/BASYARNAS/Ka. Jak, tanggal 16 September 2009. Dalam putusan tersebut BASYARNAS mengabulkan permohonan Penggugat sebagian dan menyatakan bahwa Tergugat telah cidera janji, menyatakan akad murabahah batal demi hukum, dan menghukum Tergugat untuk mengembalikan dana kepada Penggugat sebesar Rp. 878.791.366.
Terhadap putusan ini telah didaftarkan ke Pengadilan Agama Jakarta Pusat (selanjutnya ditulis PA. Jak.Pus) dengan Nomor: 01/BASYARNAS/2009/PA.JP tanggal 12 Oktober 2009. Setelah putusan didaftarkan, Tergugat mengajukan pembatalan putusan BASYARNAS ke PA. Jak.Pus, dan PA. Jak.Pus mengabulkan permohonan Tergugat dan membatalkan putusan BASYARNAS.

Selanjutnya Penggugat mengajukan banding tentang putusan PA. Jak. Pus tersebut ke MA, kemudian MA mengeluarkan Putusan No.188 K/AG/2010 tanggal 09 Juni 2010 terhadap kasus ini dan menyatakan bahwa membatalkan putusan PA. Jak.Pus, menyatakan PA. Jak.Pus tidak berwenang memeriksa dan mengadili perkara a quo, dan menyatakan menolak permohonan pembatalan putusan BASYARNAS.

Terhadap putusan MA ini, Tergugat mengajukan PK dan MA memberikan Putusan Peninjauan Kembali Nomor: 56 PK/AG/2011 tanggal 01 Desember 2011 yang menyatakan menolak permohonan PK Tergugat (PT Bank Syariah Mandiri). Sehingga putusan yang berlaku adalah putusan MA. 


\section{PEMBAHASAN}

\section{Polemik Dalam Penyelesaian Sengketa Melalui Basyarnas}

BASYARNAS sebagai lembaga arbitrase merupakan salah satu jalan penyelesaian sengketa melalui jalur non litigasi. Berdasarkan Pasal 60 UU No. 30 Tahun 1999 menyatakan bahwa putusan arbitrase bersifat final dan mempunyai kekuatan hukum tetap dan mengikat para pihak. Hal ini tentu merupakan suatu cerminan dari asas perkara cepat, sederhana, biaya ringan karena tidak ada upaya hukum terhadap putusan dari arbitrase. Namun, pelaksanaan putusan arbitrase yang bersifat final and binding tersebut terkendala karena lembaga arbitrase tersebut tidak dapat melakukan eksekusi sendiri.

Berdasarkan UU No. 30 Tahun 1999 Pasal 59 ayat (1) menyatakan bahwa lembaga arbitrase ketika telah memutus suatu perkara harus mendaftarkan putusannya tersebut kepada Panitera Pengadilan Negeri paling lama 30 hari. Konsekuensi dari tidak terpenuhinya ketentuan Pasal 59 ayat (1) tersebut adalah tidak dapat dilaksanakannya putusan arbitrase, sebagaimana yang telah dinyatakan pada Pasal 59 ayat (4) UU No. 30 Tahun 1999. Polemik lebih jauh muncul khusus untuk lembaga BAYSARNAS. Sebagai respon lahirnya lembaga keuangan syariah BASYARNAS diharapkan mampu menjadi lembaga penyelesaian sengketa non litigasi terhadap sengketa pada lembaga keuangan syariah.

Polemik ini muncul dikarenakan BASYARNAS sebagai lembaga penyelesaian sengketa non litigasi yang menerima perkara keuangan syariah tunduk kepada UU No. 30 Tahun 1999. Pada pasal 59 ayat (1) UU No. 30 tahun 1999 di atas menyatakan bahwa pendaftaran putusannya dilakukan kepada Panitera Pengadilan Negeri, sedangkan perkara tersebut adalah perkara ekonomi syariah yang merupakan kewenangan Pengadilan Agama. Hal ini mengusik kewenangan Peradilan Agama sebagai lembaga penyelesaian sengketa ekonomi syariah.

Ketidakpastian hukum ini juga terlihat pada pasal 61 UU Nomor 30 tahun 1999 juga menyatakan bahwa "Dalam hal para pihak tidak melaksanakan putusan arbitrase secara sukarela, putusan dilaksanakan berdasarkan perintah Ketua Pengadilan Negeri atas permohonan salah satu pihak yang bersengketa".

Analisis Pelaksanaan Putusan Basyarnas Ditinjau Dari Asas Kepastian Hukum, Keadilan Dan Kemanfaatan

Sengketa pada kasus diatas berkaitan dengan sengketa ekonomi syariah 
menganai akad pembiyaan murabahah. Pada pasal 49 huruf i UU tentang Peradilan Agama dijelaskan bahwa Peradilan Agama berwenang terhadap sengketa ekonomi syariah dan pada pasal 55 ayat 1 UU No 21 tahun 2008 dijelaskan bahwa yang berwenang dalam sengketa perbankan syariah adalah Pengadilan Agama. Namun pada pasal 55 ayat 2 UU No. 21 tahun 2008 dijelaskan bahwa apabila para pihak telah memperjanjikan penyelesaian sengketa di luar Pengadilan Agama, maka dilakukan sesuai dengan isi akad. Dalam hal ini para pihak dalam akad murabahah tersebut telah sepakat apabila terjadi sengketa dan tidak dapat diselesaikan dengan musyawarah, maka diselesaikan melalui BASYARNAS. Sehingga dalam hal ini telah tepat Penggugat mengajukan sengketanya ke BASYARNAS.

Setelah sengketa tersebut diputus dan BASYARNAS menerima sebagian permohonan Penggugat, putusan tersebut didaftarkan ke Pengadilan Agama. Putusan Basyarnas keluar pada 16 September 2009 dan didaftarkan pada 12 Oktober 2009. Jarak antara putusan keluar dengan pendaftaran adalah 28 hari sehingga hal ini sesuai dengan ketentuan pada pasal 59 UU No. 30 tahun 1999.

Namun pada pendaftaran yang dilakukan BASYARNAS tidak sepenuhnya sesuai dengan aturan dalam pasal 59 UU No. 30 tahun 1999. Pada pasal 59 tersebut seharusnya putusan arbitrase didaftarkan kepada panitera Pengadilan Negeri, bukan kepada Pengadilan Agama. Hal ini terjadi disebabkan adanya dualisme hukum. Disatu pihak perkara ekonomi syariah merupakan kewenangan absolute Pengadilan Agama, dipihak lain dalam aturan arbitrase pendaftaran putusan arbiter harus didaftarkan ke Pengadilan Negeri dan eksekusi putusan diberikan atas perintah Ketua Pengadilan Negeri.

Dualisme kewenangan pada lembaga peradilan kembali muncul disebabkan benturan antara kewenangan peradilan agama yang merujuk UU No. 3 Tahun 2006 melawan ketentuan tentang pendaftaran dan pelaksanaan putusan BASYARNAS melalui pengadilan negeri yang merujuk pada UU No. 30 Tahun 1999.

Peraturan yang saling berbenturan mengenai dualisme kewenangan pelaksanaan eksekusi ini tidak hanya melibatkan UU No. 3 Tahun 2006 (Pasal 49 huruf i) dan UU No. 30 tahun 1999 (Pasal 59 ayat (1) dan Pasal 61), tetapi UU No. 21 Tahun 2008 (Pasal 55 ayat (1) dan (2)), UU No. 48 Tahun 2009 (Pasal 59 ayat (3)), serta Surat Edaran Mahkamah Agung Nomor 8 Tahun 2008 (selanjutnya ditulis SEMA No. 8 Tahun 2008) danSurat Edaran Mahkamah 
Agung Nomor 8 Tahun 2010(selanjutnya disebut SEMA No. 8 Tahun 2010).

Sebab utama polemik ini muncul dikarenakan lembaga arbitrase tidak dapat melakukan eksekusi putusan sendiri, sehingga memunculkan sengketa kewenangan antara lembaga peradilan. Kemudian, tidak adanya pembaharuan hukum mengingat aturan yang mengatur tentang arbitrase dan alternatif penyelesaian sengketa sudah terlalu lama dan kini telah hadir lembaga arbitrase syariah, sehingga perlu diadakan pula pembaharuan pada peraturan terkait agar dapat menaungi seluruh peristiwa hukum yang hidup di tengah masyarakat secara menyeluruh.

BASYARNAS tergolong sebagai lembaga arbitrase dan ia pilihan alternatif penyelesaian sengketa ekonomi syariah. Adanya pertentangan pada poin peraturan ini akan menyulitkan para pencari keadilan. Ketentuan yang bertentangan ini akan menjadikan tidak terciptanya kepastian hukum. Pada Pasal 49 huruf i UU No. 3 Tahun 2006 dijelaskan bahwa Peradilan Agama berwenang terhadap sengketa ekonomi syariah dan pada Pasal 55 ayat (1) UU No. 21 Tahun 2008 dijelaskan bahwa yang berwenang dalam sengketa perbankan syariah adalah Pengadilan Agama. Polemik yang sempat terjadi pada Pasal 55 ayat (2) UU No. 21 Tahun
2008 telah selesai dengan adanya Putusan Mahkamah Konstitusi No.93/PUU-X/2012 sehingga Peradilan Agama menjadi satusatunya lembaga peradilan penyelesaian sengketa ekonomi syariah.

Namun pada UUNo.30 tahun1999Pasal 59 ayat (1) dijelaskan bahwa pendaftaran putusan lembaga Arbitrase didaftarkan pada Panitera Peradilan Negeri. Dalam Pasal 61 undang-undang tersebut juga menjelaskan bahwa dalam hal para pihak tidak melaksanakan putusan arbitrase secara sukarela, putusan dilaksanakan berdasarkan perintah Ketua Pengadilan Negeri atas permohonan salah satu pihak yang bersengketa. Ketentuan ini tentu telah mengganggu eksistensi Peradilan Agama sebagai lembaga peradilan yang berwenang pada sengketa ekonomi syariah.

Untuk menyelesaikan pertentangan peraturan dalam sistem perundangundangan pada umumnya digunakan tiga macam asas hukum yaitu: (kansil dan kansil, 2011: 151)

a) Asas Lex Superiori Derogat Legi Inferiori.

b) Asas Lex Posteoriori Derogat Legi Priori.

c) Asas Lex Specialis Derogat Legi Generalis.

Ketiga asas tersebut digunakan jika terdapat ketidakharmonisan antara peraturan perundang-undangan dan 
menentukan aturan mana yang seharusnya lebih diutamakan untuk berlaku.

Asas Lex Posterior Derogat Legi Priori yang menyatakan bahwa pada peraturan yang sederajat, peraturan yang paling baru melumpuhkan peraturan yang lama, asas ini tidak bisa diterapkan untuk menyelesaikan pertentangan peraturan dualisme kewenangan peradilan ini, karena masing-masing dari undang-undang yang bertabrakan disini mengatur pokok yang berbeda. UU No. 3 Tahun 2006 tersebut membahas tentang Peradilan Agama sedangkan UU No 30 Tahun 1999 membahas tentang alternatif penyelesaian sengketa. Meskipun UU No. 3 Tahun 2006 diundangkan setelah adanya UU No 30 Tahun 1999, namun bukan berarti UU UU No. 3 Tahun 2006 dapat mencabut UU No 30 Tahun 1999, karena keduanya mengatur dua hal yang berbeda oleh karena pokok pembahasan kedua undang-undang ini tidak sama maka mereka tidak bisa saling menghapus.

Mengingat bahwa keduanya adalah peraturan yang berbentuk UndangUndang maka asas lex superior derogat legi inferior pun tidak dapat diterapkan dalam menyelesaikan pertentangan peraturan ini, karena asas ini dipergunakan untuk menyelesaikan pertentangan antara peraturan yang lebih tinggi dengan yang rendah (asas hierarki).

Jika dilihat dari asas Lex spesialis derogat lex generalis, maka terdapat benturan dalam hal ini. Jika dilihat dari jenis sengketanya (ekonomi syariah) maka UU No 3 Tahun 2006 yang harus digunakan sehingga Peradilan Agama yang berwenang, namun jika dilihat dari kewenangan dalam pelaksanaan putusan Arbitrase delam UU No 30 tahun 1999 maka Peradilan Umum yang berwenang.

Selanjutnya kekuatan hukum Peradilan Agama sebagai pelaksana eksekusi dipertegas dengan adanya SEMA No 8 Tahun 2008 yang menyatakan bahwa Ketua Pengadilan Agama berwenang memerintahkan pelaksanaan putusan Arbitrase Syariah nasional. Namun SEMA ini tidak berlangsung lama, MA membatalkan SEMA No 8 tahun 2008 yang menyatakan eksekusi putusan BASYARNAS adalah kewenangan Peradilan Agama melalui SEMA No. 8 tahun 2010 ini didasari oleh Pasal 59 angka 3 UU No. 48 Tahun 2009, dalam SEMA ini MA menyatakan apabila putusan BASYARNAS tidak dijalankan secara sukarela, maka putusan dilaksanakan berdasarkan perintah Peradilan Umum berdasarkan permohonan salah satu pihak yang bersengketa. 
Dosen fikih muamalah ekonomi pascasarjana Universitas Indonesia, Agustianto menilai SEMA yang baru dikeluarkan tersebut sebagai sebuah kemunduran. Ia menyatakan "lebih bagus SEMA yang lama yang secara tegas menyebutkan sebagai kewenangan pengadilan agama". (Hukumonline.com, dualisme eksekusi putusan Basyarnas masih berlanjut)

Adanya tumpang tindih hukum ini tidak mencerminkan adanya kepastian hukum. Hal ini dilatarbelakangi karena putusan BASYARNAS yang harus didaftarkan ke pengadilan serta proses eksekusi yang harus mendapat perintah pengadilan. Jika dilihat dari sifat putusan arbitrase (BASYARNAS) yang bersifal final and binding seharusnya ketika perkara tersebut diputus, putusan dapat langsung dijalankan tanpa perlu pendaftaran dan perintah eksekusi dari ketua Pengadilan Negeri, namun hal ini wajar karena lembaga peradilan yang berwenang hanyalah lembaga peradilan yang berada dibawah MA sebagaimana dijelaskan dalam UUD Pasal 24 (2) dinyatakan bahwa "Kekuasaan kehakiman dilakukan oleh sebuah Mahkamah Agung dan badan peradilan yang berada di bawahnya dalam lingkungan peradilan umum, lingkungan peradilan agama, lingkungan peradilan militer, lingkungan peradilan tata usaha negara, dan oleh sebuah Mahkamah Konstitusi".

Jika ditinjau dari tujuan hukum, permasalahan dualisme kewenangan pada pelaksanaan putusan BASYARNAS di atas permasalahan mendasarnya adalah karena putusan tersebut tidak bisa dieksekusi kecuali setelah mendapat perintah dari Pengadilan Negeri. tujuan hukum sangat beragam, namun dapat disimpulkan bahwa tujuan hukum tersebut terbagi kepada 3 klasifikasi. Pertama, keadilan. Hal ini diungkapkan oleh aliran etis yang menyatakan bahwa pada prinsipnya tujuan hukum itu hanya mencari keadilan. Kedua, kemanfaatan. Menurut aliran utilitis tujuan dari hukum hanya untuk meciptakan kebahagaiaan atau kemanfaatan. Ketiga, kepastian hukum. Aliran normatif yuridis menyatakan bahwa tujuan hukum adalah untuk menciptakan kepastian hukum. (Rifai, 2010: 129-130)

Suatu putusan yang tidak dapat dieksekusi tentu tidak mencerminkan nilai kemanfaatan dan juga tidak mencerminkan keadilan. Karena meskipun putusan tersebut telah melalui prosedur yang semestinya namun jika tidak bisa dijalankan maka putusan tersebut tidak akan ada gunaya. Suatu putusan yang tidak bisa dijalankan sama halnya dengan putusan hampa dan tidak dapat memberikan 
keadilan kepada pihak yang dirugikan. Adanya dualisme hukum ini tentu tidak mencerminkan asas kepastian hukum. Para pencari keadilan menjadi kesulitan untuk mendapat keadilan dikarenakan adanya dualisme hukum.

\section{PENUTUP}

Dari uraian di atas dapat disimpukan bahwa UU No. 30 Tahun 1999 yang mengatur tentang arbitrase dan alternatif penyelesaian sengketa telah dapat memayungi BASYARNAS. Penyelesaian sengketa melalui BASYARNAS terkendala dalam hal pelaksanaan putusan. BASYARNAS sebagai lembaga arbitrase yang menyelesaikan sengketa ekonomi syariah dalam meminta eksekusi putusan berada pada posisi yang sulit karena disatu sisi perkara tersebut adalah perkara ekonomi syariah yang merupakan kewenangan Peradilan Agama, disisi lain menurut UU No 30 tahun 1999 pelaksanaan eksekusi putusan arbitrase melalui perintah ketua Pengadilan Negeri.

Lahirnya SEMA No 8 tahun 2008 yang salah satu poinnya mengatur ekseskusi putusan BASYARNAS yang kemudian dibatalkan dengan SEMA No 8 tahun 2010 memperlihatkan kompleksnya masalah dalam eksekusi putusan BASYARNAS. Bagaimanapun putusan yang dikeluarkan tidak akan memberikan keadilan dan berguna jika putusan tersebut tidak dapat dijalankan. Adanya tumpang tindih hukum ini menjadikan proses penyelesaian sengketa melalui BASYARNAS menjadi rumit.

\section{DAFTAR KEPUSTAKAAN}

Ali, Zainuddin. 2011. Metode Penelitian Hukum. Jakarta: Sinar Grafika.

Ansori, Abdul Ghofur. 2007. Perbankan Syariah di Indonesia. Yogyakarta: Gajah Mada University Press.

Dewi, Gemala. 2006. Aspek-aspek Hukum dalam Perbankan dan Perasuransian Syariah di Indonesia. edisi revisi. Jakarta: Kencana.

Dimiyati, Ahmad. 1994. Sejarah Lahirnya BAMUI dalam Arbitrase Islam di Indonesia. Jakarta: BAMUI dan Bank Muamalat.

Dimyati, Khudzaifah dan Wardiono, Kelik. 2004. Metode Penelitian Hukum, Surakarta: UMS Press.

Emrizon, Joni. 2008. Hukum Bisnis Indonesia. Jakarta: CV Literata Lintas Media.

Iska, Syukri. 2012. Sistem Perbankan Syariah di Indonesia. Yogyakarta: Fajar Media Press. 
Kansil, C.S.T., dan Kansil, Christine S.T. 2011. Pengantar Ilmu Hukum Indonesia. Jakarta: PT. Rineka Cipta.

Magono, Suyud. 2000. ADR (Alternative Dispute Resolution) \& Arbitrase: Proses Pelembagaan dan Aspek Hukum. Cet I. Jakarta: Ghalia Indonesia.

Miru, Ahmad dan Pati, Sakka. 2008. Hukum Perikatan. Jakarta: PT Raja Grafindo Persada.

Rifai, Ahmad. 2010. Penemuan Hukum Oleh Hakim dalam Presfektif Hukum Progresif. Jakarta: Sinar Grafika.

Saliman, Abdul Rasyid. 2005. Hukum Bisnis Untuk Perusahaan: Teori dan Contoh Kasus, Jakarta: Kencana Prenadamedia Group.

Soejono dan Mamudji, Sri. 2007. Penelitian Hukum Normatif: Suatu Tinjauan Singkat. Jakarta: PT. Radja Grafindo Persada.

Sumardjono, Maria SW. 2005. Metodologi Penelitian Ilmu Hukum. Yogyakarta: Universitas Gajah Mada.
Sumitro, Warkum. 1997. Asas-asas Perbankan Islam dan Lembaga-lembaga Terkait (BAMUI \& TAKAFUL) di Indonesia. Jakarta: PT Raja Grafindo Persada.

$-$ --. 2004. Asas-asas Perbankan Islam dan Lembaga-lembaga Terkait (BAMUI, Takaful dan pasar Modal Syari'ah di Indonesia). Jakarta: Raja Grafindo Persada.

http://journal.uinjkt.ac.id/index.php/ ahkam/article/view/4457/3185 Ahkam: Vol. XVI, No. 2, Juli 2016. Nurhasanah dan Nasution, Hotnidah. Kecenderungan Masyarakat Memilih Lembaga Penyelesaian Sengketa Ekonomi Syariah. Diakses pada hari selasa, 25 April 2017, pukul 16:02 http://www.hukumonline.com/berita/ baca/1t4c0d0adad7fb1/dualismeeksekusi-putusan-basyarnas-masihberlanjut diakses pada hari selasa, 25 April 2017, pukul 16:05. 